\title{
Amyloidosis in a child with Hyperimmunoglobulin D syndrome
}

\author{
Ruhan Dusunsel ${ }^{1 *}$, Zubeyde Gunduz' ${ }^{1}$ Funda Bastug ${ }^{1}$, Ismail Dursun ${ }^{1}$, Hakan M Poyrazoglu' ${ }^{1}$, Sibel Yel', \\ Sebahat Tulpar ${ }^{1}$, Kemal Deniz $^{2}$, Erkan Demirkaya ${ }^{3}$ \\ From 18th Pediatric Rheumatology European Society (PReS) Congress \\ Bruges, Belgium. 14-18 September 2011
}

\section{Background and aim}

Amyloidosis in children autoinflammatory disease is one of the most important unfavorable outcomes.

\section{Case}

A-7 year old boy was admitted with complaints of edema on his eyelid and lower extremity. On admission, he had edema, hepatosplenomegaly, proteinuria and hypoalbuminemia. So his diagnosis was accepted as nephrotic syndrome and steroid therapy was started. Since he did not respond steroid therapy, kidney biopsy was performed. Biopsy findings were consistent with amyloidosis. Steroid therapy was ceased and colchicine was started. The patient was reevaluated for autoinflammatory diseases. His parent told that he had slightly periodic fever and he had no abdominal pain, arthritis, pleuritis and erysipelas-like erythema. MEFV mutation was normal. Other autoinflammatory syndromes were investigated and he had elevated serum IgD concentration. Mevalonate kinase gene mutation was positive for G326R/V377I. His diagnosis was Hyperimmunoglobulin D syndrome (HIDS). Having a poor response to colchium therapy, anti-TNF therapy (etanercept) was planned.

\section{Conclusion}

Amyloidosis in children with HIDS was rarely reported. In literature, we present the first report of the occurrence of renal AA amyloidosis causing severe nephrotic syndrome, in a Turkish children affected with HIDS.

\footnotetext{
* Correspondence: druhan@erciyes.edu.tr

${ }^{1}$ Erciyes University Faculty of Medicine Department of Pediatric Nephrology and Rheumatology, Turkey
}

Full list of author information is available at the end of the article
Author details

${ }^{1}$ Erciyes University Faculty of Medicine Department of Pediatric Nephrology and Rheumatology, Turkey. ${ }^{2}$ Department of Pathology, Kayseri, Turkey.

${ }^{3}$ Gulhane Military School Department of Pediatric Nephrology and

Rheumatology, Ankara, Turkey.

Published: 14 September 2011

doi:10.1186/1546-0096-9-S1-P2

Cite this article as: Dusunsel et al:: Amyloidosis in a child with

Hyperimmunoglobulin D syndrome. Pediatric Rheumatology 2011 9(Suppl 1):P2.
Submit your next manuscript to BioMed Central and take full advantage of:

- Convenient online submission

- Thorough peer review

- No space constraints or color figure charges

- Immediate publication on acceptance

- Inclusion in PubMed, CAS, Scopus and Google Scholar

- Research which is freely available for redistribution

Submit your manuscript at www.biomedcentral.com/submit
( Biomed Central
C Biomed Central

(c) 2011 Dusunsel et al; licensee BioMed Central Ltd. This is an open access article distributed under the terms of the Creative Commons Attribution License (http://creativecommons.org/licenses/by/2.0), which permits unrestricted use, distribution, and reproduction in any medium, provided the original work is properly cited. 